\title{
Clinical Resource Contractor
}

National Cancer Institute

\section{Source}

National Cancer Institute. Clinical Resource Contractor. NCI Thesaurus. Code C54146.

A person, group, or organization that agrees to furnish something of, relating to, or connected with a clinic that can be used for support or help at a specified price. 